\title{
Mitigating the wider health effects of covid-19 pandemic response
}

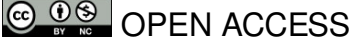

\section{Margaret Douglas MPH programme co-director ${ }^{12}$, Srinivasa Vittal Katikireddi clinical senior research fellow $^{2}{ }^{3}$, Martin Taulbut information manager ${ }^{2}$, Martin McKee professor of European public health ${ }^{4}$, Gerry McCartney consultant in public health ${ }^{2}$}

\begin{abstract}
${ }^{1}$ Usher Institute, University of Edinburgh, Edinburgh, UK; ${ }^{2}$ Public Health Scotland, Glasgow, UK; ${ }^{3} \mathrm{MRC} / \mathrm{CSO}$ Social and Public Health Sciences Unit, University of Glasgow, Glasgow, UK; ${ }^{4}$ London School of Hygiene and Tropical Medicine, London, UK; Correspondence to: M Douglas margaret.douglas@ed.ac.uk
\end{abstract}

Countries worldwide have implemented strict controls on movement in response to the covid-19 pandemic. The aim is to cut transmission by reducing close contact (box 1), but the measures have profound consequences. Several sectors are seeing steep reductions in business, and there has been panic buying in shops. Social, economic, and health consequences are inevitable.

\footnotetext{
Box 1: Social distancing measures

Advising the whole population to self-isolate at home if they or their family have symptoms

- Bans on social gatherings (including mass gatherings)

- Stopping flights and public transport

- Closure of "non-essential" workplaces (beyond the health and social care sector, utilities, and the food chain) with continued working from home for those that can

- Closure of schools, colleges, and universities

- Prohibition of all "non-essential" population movement

- Limiting contact for special populations (eg, care homes, prisons)
}

The health benefits of social distancing measures are obvious, with a slower spread of infection reducing the risk that health services will be overwhelmed. But they may also prolong the pandemic and the restrictions adopted to mitigate it. ${ }^{1}$ Policy makers need to balance these considerations while paying attention to broader effects on health and health equity.

\section{Who is most at risk?}

Several groups may be particularly vulnerable to the effects of both the pandemic and the social distancing measures (box 2). Table 1 summarises several mechanisms through which the pandemic response is likely to affect health: economic effects, social isolation, family relationships, health related behaviours, disruption to essential services, disrupted education, transport and green space, social disorder, and psychosocial effects. Figure 1 shows the complexity of the pathways through which these effects may arise. Below we expand on the first three mechanisms, using Scotland as an example. The appendix on bmj.com provides further details of mechanisms, effects, and mitigation measures. 


\section{Box 2: Groups at particular risk from responses to covid-19}

- Older people-highest direct risk of severe covid-19, more likely to live alone, less likely to use online communications, at risk of social isolation

- Young people-affected by disrupted education at critical time; in longer term most at risk of poor employment and associated health outcomes in economic downturn

- Women-more likely to be carers, likely to lose income if need to provide childcare during school closures, potential for increase in family violence for some

- People of East Asian ethnicity-may be at increased risk of discrimination and harassment because the pandemic is associated with China

- People with mental health problems-may be at greater risk from social isolation

- People who use substances or in recovery—risk of relapse or withdrawal

- People with a disability—affected by disrupted support services

- People with reduced communication abilities (eg, learning disabilities, limited literacy or English language ability)—may not receive key governmental communications

- Homeless people-may be unable to self-isolate or affected by disrupted support services

- People in criminal justice system—difficulty of isolation in prison setting, loss of contact with family

- Undocumented migrants-may have no access to or be reluctant to engage with health services

- Workers on precarious contracts or self-employed-high risk of adverse effects from loss of work and no income

- People on low income - effects will be particularly severe as they already have poorer health and are more likely to be in insecure work without financial reserves

- People in institutions (care homes, special needs facilities, prisons, migrant detention centres, cruise liners)—as these institutions may act as amplifiers

\section{Economic effects}

People may experience loss of income from social distancing in several ways. Although some people can work at home, many cannot, especially those in public facing roles in service industries, a group that already faces precarious employment and low income. ${ }^{2}$ Others may be affected by workplace closures, caused by government mandate, an infected co-worker, or loss of business. Yet more may be unable to work as school closures require them to provide childcare. In the UK, 3.5 million additional people are expected to need universal credit (which includes unemployment payments) as a result of the pandemic. ${ }^{3}$

The growth of the informal, gig economy in some countries has created a large group of people who are especially vulnerable as they do not get sick pay, are on zero hours contracts, or are self-employed. ${ }^{4}$ They can easily lose all their income, and even if this is only temporary they often lack the safety net of savings. An important risk is housing security, with loss of income causing rent or mortgage arrears or even homelessness.

School closure will affect low income and single parent families especially severely because they need to meet an unexpected need for childcare and lose the benefit of free school meals. They may also face increased costs for heating their homes during the day. In some countries, welfare systems impose strict conditions on recipients that cannot be met by those in isolation.

The link between income and health is well established and acts through several mechanisms. ${ }^{5}$ Income allows people to buy necessities for life, access health enhancing resources, avoid harmful exposures, and participate in normal activities of society. Low income also increases psychosocial stress. The minimum income for healthy living establishes a standard required to maintain health in different settings. ${ }^{6}$ Crucially, not everyone is equally likely to lose income. Women, young people, and those who are already poor will fare worst. To avoid widening health inequalities, social distancing must be accompanied by measures to safeguard the incomes of poor people.

\section{Future challenges}

The longer term effects may be substantial. If businesses fail, many employees will become unemployed. Those losing their jobs in middle age may never return to the workforce. Sectors that are especially vulnerable include hospitality, entertainment, transport, leisure, and sport. Unemployment has large negative effects on both physical and mental health, ${ }^{7}$ with a meta-analysis reporting a $76 \%$ increase in all-cause mortality in people followed for up to 10 years after becoming unemployed. ${ }^{8}$

The pandemic has already caused downgrading of economic forecasts, with many countries facing a recession. The health consequences of a recession are complex. Economic downturns have been associated with improvements in some health outcomes, especially traffic injuries, but worsening mental health, including increases in homicide and suicide. ${ }^{9}$ However, these harmful effects can be prevented by progressive social policies; it is the policy response to a recession, rather than the recession itself, that determines longer term population health. ${ }^{10}$

Throughout history, some people have viewed any crisis as an opportunity. Klein described how "disaster capitalists" take advantage of natural and human influenced disasters. ${ }^{11}$ There is clear potential for price gouging (profiteering through increased prices during supply or demand shocks) on essential goods. Once the pandemic recedes, there could be profound changes to the economy that may disadvantage less powerful populations, such as through privatisation of public sector services. However, there may also be opportunities for the economy to be rebuilt "better," depending on public and political attitudes and power balance. ${ }^{12}$

\section{Social isolation}

Advising or compelling people to self-isolate at home risks serious social and psychological harm. Quarantine of people exposed to an infectious disease is associated with negative psychological effects, including post-traumatic stress symptoms, which may be long lasting. ${ }^{13}$ The effects are exacerbated by prolonged isolation, fear of the infection, frustration, boredom, inadequate supplies and information, financial loss, and stigma. These effects are less when quarantine is voluntary and can be mitigated by ensuring clear rapid communication, keeping the duration short, providing food and other essential supplies, and protecting against financial loss. ${ }^{13}$

In Scotland, a third of the population lives alone and $40 \%$ of this group are of pensionable age. ${ }^{14}$ Older people are also less likely to use online communications, making them at particular risk of social isolation during social distancing. Social isolation is defined as pervasive lack of social contact or communication, participation in social activities, or a confidante.

Long term, social isolation is associated with an increase in mortality of almost a third. ${ }^{15}$ Prolonged periods of social distancing could have similar effects. People who are socioeconomically disadvantaged or in poor physical or mental health are at higher risk. ${ }^{16}$ Online and telephone support needs to be provided for vulnerable groups, especially those living alone.

\section{Family relationships}

Social distancing measures will place many people in close proximity with family members all or most of the time, which 
may cause or exacerbate tensions. Concern has been raised about potential increases in family violence during restrictions in the UK. ${ }^{17}$ Risk factors for partner and child abuse include poverty, substance misuse in the home, and previous history of abuse. ${ }^{18} 19$ Around 60000 domestic abuse incidents occur in Scotland every year, with young women most affected, ${ }^{20}$ and over 2500 children are on the child protection register. ${ }^{21}$

It is important to maintain social work and community support for vulnerable families, including safety advice for women at risk of abuse. Domestic abuse advocates have called for enhanced support, including allocation of hotel rooms for women at risk. ${ }^{17}$

School closures may add to stress in families as parents try to home school children, often juggling this with home working. This burden may fall disproportionately on women. As well as academic learning, schools support development of social and other skills. Prolonged school closures could cause adverse effects on educational and social outcomes for young people in families that lack study space and access to home computing. ${ }^{22}$ Some children who are not at school may be at risk of online or other forms of exploitation-for example, by drug dealers-or of being recruited into gangs. Realistic expectations of home schooling, provision of food for those eligible for free school meals, and outreach support for the most vulnerable children will be needed during school closures. Many children will need extra support on return to school. ${ }^{22}$

\section{Mitigating adverse effects}

In addition to the direct disease burden from covid-19, the pandemic response is already causing negative indirect effects such as those described above. These are borne

disproportionately by people who already have fewer resources and poorer health. Prolonged or more restrictive social distancing measures could increase health inequalities in the short and long term.

Our assessment is based on rapid scoping of potential impacts and a non-systematic review of diverse publications, so there is a high degree of uncertainty about the extent of some impacts. However, the range of health concerns identified, beyond those directly attributable to the virus itself, should be recognised in developing and implementing responses. The effects may also vary by context. In low and middle income countries without social safety nets, the effects on population health and health inequalities are likely to be worse than in richer countries, as is beginning to be seen in India. ${ }^{23}$

Actions must be targeted to support the most vulnerable people. The extraordinary measures in the UK to allow businesses to continue paying staff will help mitigate the harms for many workers. But it is important to consider people in precarious work who will not be covered by these measures, and to consider longer term support for those who continue to experience problems once the measures expire. A large multiagency response will be needed to deal with the wide range of needs we have identified.

In the longer term, policy decisions made now will shape the future economy in ways that could either improve or damage sustainability, health, and health inequalities. These include decisions about which sectors to prioritise for support, whether to direct financial support to business or workers, and how to fund the costs. To protect population health it will be essential to avoid a further period of austerity and the associated reductions in social security and public service spending. Instead we must build a more sustainable and inclusive economy. ${ }^{10}$

\section{Key messages}

Social distancing measures to control the spread of covid-19 are likely to have large effects on health and health inequalities

These effects have numerous mechanisms, including economic, social, health related behaviours, and disruption to services and education

People on low incomes are most vulnerable to the adverse effects Substantial mitigation measures are needed in the short and long term

SVK acknowledges funding from a NRS senior clinical fellowship (SCAF/15/02), the Medical Research Council (MC_UU_12017/13), and the Scottish Government Chief Scientist Office (SPHSU13).

Contributors and sources: MD chairs the Scottish Health and Inequalities Impact Assessment Network. SVK has research interests in social determinants of health and healthy public policy. MT has expertise in quantitative social research and social policy. MMcK is research director of the European Observatory on Health Systems and Policies. GMcC is head of the Scottish Public Health Observatory. MD used a health impact assessment checklist to identify potential mechanisms. GMcC, MD, SVK, and MT prepared the analysis of impacts shown in the table in the appendix. All authors debated and agreed the findings and contributed to the text of the paper.

Competing interests: We have read and understood BMJ policy on declaration of interests and have no relevant interests to declare.

Provenance and peer review: Not commissioned; externally peer reviewed.

1 Ferguson NM, Laydon D, Nedjati-Gilani G, et al. Impact of non-pharmaceutical interventions (NPIs) to reduce COVID19 mortality and healthcare demand. London, Imperial College COVID-19 response team, 16 March 2020. https://www.imperial.ac.uk/media/imperialcollege/medicine/sph/ide/gida-fellowships/Imperial-College-COVID19-NPI-modelling-1603-2020.pdf

2 McKee M, Reeves A, Clair A, Stuckler D. Living on the edge: precariousness and why it matters for health. Arch Public Health 2017;75:13. 10.1186/s13690-017-0183-y. 28270912

3 Benstead S. Coronavirus to force 3.5 million extra people on to universal credit. Telegraph 2020 Apr 9. https://www.telegraph.co.uk/money/consumer-affairs/coronavirus-force-35million-extra-people-universal-credit

4 Kuhn KM. The rise of the "gig economy" and implications for understanding work and workers. Ind Organ Psychol 2016;9:157-62. 10.1017/iop.2015.129.

5 Benzeval M, Bond L, Campbell C, et al. How does money influence health? Joseph Rowntree Foundation, 2014. https://www.jrforg.uk/sites/default/files/jrf/migrated/files/ income-health-poverty-full.pdf

6 Morris JN, Donkin AJM, Wonderling D, Wilkinson P, Dowler EA. A minimum income for healthy living. J Epidemiol Community Health 2000;54:885-9. 10.1136/jech.54.12.885. 11076983

7 Paul KI, Moser K. Unemployment impairs mental health: meta-analyses. J Vocat Behav 2009;74:264-82. 10.1016/j.jvb.2009.01.001.

8 Roelfs DJ, Shor E, Davidson KW, Schwartz JE. Losing life and livelihood: a systematic review and meta-analysis of unemployment and all-cause mortality. Soc Sci Med 2011;72:840-54. 10.1016/j.socscimed.2011.01.005. 21330027

9 Stuckler D, Basu S, Suhrcke M, Coutts A, McKee M. The public health effect of economic crises and alternative policy responses in Europe: an empirical analysis. Lancet 2009;374:315-23. 10.1016/S0140-6736(09)61124-7. 19589588

10 McCartney G, Hearty W, Arnot J, Popham F, Cumbers A, McMaster R. Impact of political economy on population health: a systematic review of reviews. Am J Public Health 2019;109:e1-12. 10.2105/AJPH.2019.305001. 31067117

11 Klein N. The shock doctrine. Harmandsworth, 2007.

12 Harris P, Baum F, Friel S, Mackean T, Schram A, Townsend B. A glossary of theories for understanding power and policy for health equity. $J$ Epidemiol Community Health 2020;20:jech-2019-213692. 10.1136/jech-2019-213692. 32198290

13 Brooks SK, Webster RK, Smith LE, etal . The psychological impact of quarantine and how to reduce it: rapid review of the evidence. Lancet 2020;395:912-20. 10.1016/S0140-6736(20)30460-8. 32112714

14 Scottish Government. A connected Scotland: our strategy for tackling social isolation and Ioneliness and building stronger social connections. 2018. https://www. gov.scotpublications/oormectedscottand-strategytadkingsociatisolationtonelinesstbuildingstrongersocial-oonnections/

15 Holt-Lunstad J, Smith TB, Baker M, Harris T, Stephenson D. Loneliness and social isolation as risk factors for mortality: a meta-analytic review. Perspect Psychol Sci 2015;10:227-37. 10.1177/1745691614568352. 25910392

16 Teuton J. Social isolation and loneliness in Scotland: a review of prevalence and trends. NHS Health Scotland, 2018.

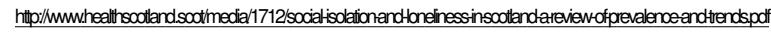

7 Public Interest Law Centre. Letter to secretary of state for housing, communities and local government, 31 March 2020. https://www.pilc.org.uk/wp-content/uploads/2020/03/ 20200331-Letter-to-MHCLG-DV-and-Covid-19-final-1.pdf

18 NICE. Domestic violence and abuse: multi-agency working. Public health guideline [PH50]. 2014. https://www.nice.org.uk/guidance/ng76/chapter/Recommendations\#assessing-riskand-need-in-relation-to-child-abuse-and-neglect

19 NICE. Child abuse and neglect. NICE guideline [NG76]. 2017. https://www.nice.org.uk guidance/ph50/chapter/3-Context

20 Scottish Government. Domestic abuse statistics 2018-19. https://www.gov.scot/publications/domestic-abuse-scotland-2018-2019-statistics/

21 Scottish Government. Children's social work statistics Scotland. 2018-2019. https://www.gov.scot/publications/childrens-social-work-statistics-scotland-2018-2019/pages/4 
22 Burgess S, Sievertsen HH. Schools, skills, and learning: The impact of COVID-19 on education CEPR Policy Portal, 2020. https://voxeu.org/article/impact-covid-19-education 23 Roy A. The pandemic is a portal. Financial Times 2020 Apr 3. https://www.ft.com/content/ 10d8f5e8-74eb-11ea-95fe-fcd274e920ca

(c) Author(s) (or their employer(s)) 2019. Re-use permitted under CC BY-NC. No commercial re-use. See rights and permissions. Published by
BMJ.http://creativecommons.org/licenses/by-nc/4.0/This is an Open Access article distributed in accordance with the Creative Commons Attribution Non Commercial (CC BY-NC 4.0) license, which permits others to distribute, remix, adapt, build upon this work non-commercially, and license their derivative works on different terms, provided the original work is properly cited and the use is non-commercial. See: http://creativecommons. org/licenses/by-nc/4.0/. 


\section{Table}

\section{Table 1| Health effects of social distancing measures and actions to mitigate them}

\begin{tabular}{|c|c|c|}
\hline Mechanism & Summary of effects & Summary of mitigations \\
\hline Economic effects & $\begin{array}{l}\text { - Income losses for workers unable to work } \\
\text { - Longer term increase in unemployment if businesses fail } \\
\text { - Recession }\end{array}$ & $\begin{array}{l}\text { - Protect incomes at the level of the minimum income for healthy } \\
\text { living } \\
\text { - Provide food and other essential supplies } \\
\text { - Reduce longer term unemployment } \\
\text { - Prioritise inclusive and sustainable economic development during } \\
\text { recovery }\end{array}$ \\
\hline Social isolation & $\begin{array}{l}\text { - Lack of social contact, particularly for people who live alone and } \\
\text { have less access to digital connectivity } \\
\text { - Difficulty accessing food and other supplies }\end{array}$ & $\begin{array}{l}\text { - Encourage and support other forms of social contact } \\
\text { - Provide supplies } \\
\text { - Provide clear communications } \\
\text { - Restrict duration of isolation }\end{array}$ \\
\hline Family relationships & $\begin{array}{l}\text { - Home confinement may increase family violence and abuse } \\
\text { - Potential exploitation of young people not in school }\end{array}$ & $\begin{array}{l}\text { - Offer support to vulnerable families } \\
\text { - Ensure realistic expectations for home working and home } \\
\text { schooling } \\
\text { - Provide safety advice and support services for women at risk of } \\
\text { domestic abuse }\end{array}$ \\
\hline Health related behaviours & $\begin{array}{l}\text { - Potential for increased substance use, increased online gambling, } \\
\text { and a rise in unintended pregnancies } \\
\text { - Reduction in physical activity as sports facilities closed and less } \\
\text { utilitarian walking and cycling }\end{array}$ & $\begin{array}{l}\text { - Advice and support on substance use, gambling, contraception } \\
\text { - Encourage daily physical activity }\end{array}$ \\
\hline $\begin{array}{l}\text { Disruption to essential } \\
\text { services }\end{array}$ & $\begin{array}{l}\text { - Direct effects on health and social care demand } \\
\text { - Unwillingness to attend healthcare settings may affect care of other } \\
\text { conditions } \\
\text { - Loss of workforce may affect essential services }\end{array}$ & $\begin{array}{l}\text { - Robust business continuity planning } \\
\text { - Prioritise essential services including healthcare, social care, } \\
\text { emergency services, utilities, and the food chain } \\
\text { - Guidance, online consultations, and outreach, for conditions other } \\
\text { than covid-19 } \\
\text { - Attention to supply chains for non-covid medicines }\end{array}$ \\
\hline Disruption to education & $\begin{array}{l}\text { - Loss of education and skills, particularly for young people at critical } \\
\text { transitions } \\
\text { - Likely increase in educational inequalities from reliance on home } \\
\text { schooling }\end{array}$ & $\begin{array}{l}\text { - Provide support for young people in critical transitions, and low } \\
\text { income or at-risk children and young people who lack IT and good } \\
\text { home study environments }\end{array}$ \\
\hline $\begin{array}{l}\text { Traffic, transport, and } \\
\text { green space }\end{array}$ & $\begin{array}{l}\text { - Reduced aviation and motorised traffic with reduced air pollution, } \\
\text { noise, injuries, and carbon emissions in short term } \\
\text { - Restricted public transport may reduce access for people without } \\
\text { a car } \\
\text { - Longer term reluctance to use public transport may increase use } \\
\text { of private cars } \\
\text { - Restricted access to green space, which has benefits for physical } \\
\text { and mental health }\end{array}$ & $\begin{array}{l}\text { - Discourage unnecessary car journeys } \\
\text { - Support active travel modes } \\
\text { - Support safe access to green spaces } \\
\text { - Post-pandemic support for public transport }\end{array}$ \\
\hline Social disorder & $\begin{array}{l}\text { - Potential for unrest if supplies run out or there is widespread } \\
\text { discontent about the response } \\
\text { - Harassment of people believed to be at risk of transmitting the virus }\end{array}$ & $\begin{array}{l}\text { - Mitigation of other effects will reduce risk of social disorder } \\
\text { - Avoid stigmatising ill people or linking the pandemic to specific } \\
\text { populations }\end{array}$ \\
\hline Psychosocial impacts & $\begin{array}{l}\text { - High level of public fear and anxiety } \\
\text { - Community cohesion could increase as people respond collectively }\end{array}$ & $\begin{array}{l}\text { - Provide clear communications } \\
\text { - Support community organisations responding to local needs }\end{array}$ \\
\hline
\end{tabular}


Figure

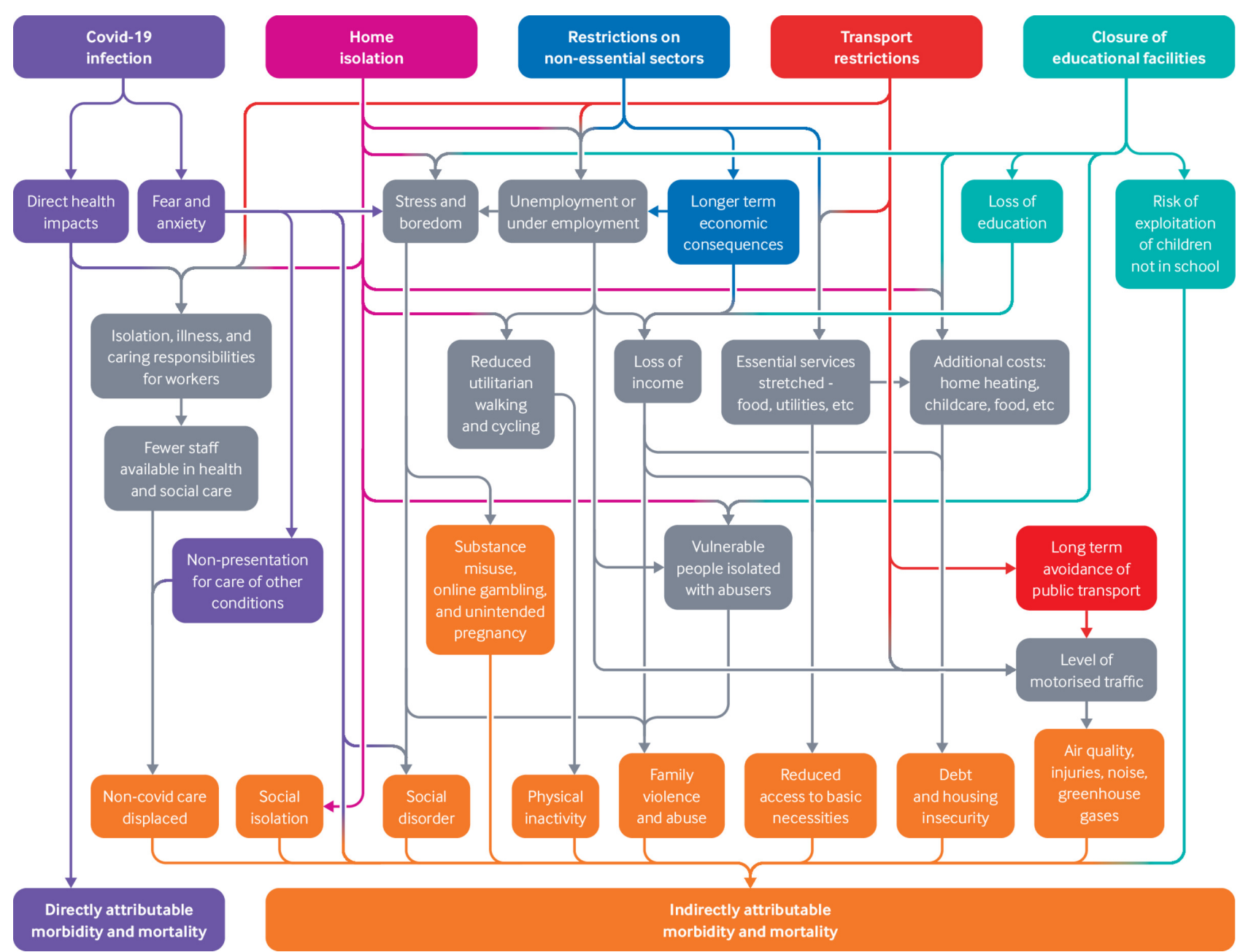

Fig 1 Effects of social distancing measures on health 